Zsuzsa Király-Véghely, Ágnes M. Móricz, Klára H. Otta and György Kátay: Evaluation of hungarian wines for resveratrol by overpressured layer chromatography. Journal of Planar Chromatography - Modern TLC 26 (2013) 160-164. DOI: 10.1556/JPC.26.2013.2.10

http://akademiai.com/content/q48u44447215730v/?p=a6a6ad0d651f4cc387a8e297cd497bfd\& $\mathrm{pi}=10$

\title{
Evaluation of Hungarian Wines for Resveratrol by Overpressured Layer Chromatography
}

\author{
Zsuzsa Király-Véghely, Ágnes M. Móricz, Klára H. Otta, György Kátay ${ }^{*}$
}

\section{Keywords}

OPLC

SPE

Resveratrol

Wine

Zsuzsa Király-Véghely, Research Institute for Viticulture and Enology, Experimental Wine Cellar, Ministry of Agriculture, Budapest, Maláta u. 4, H-1105 Hungary; György Kátay, Ágnes M. Móricz, Plant Protection Institute, Centre for Agricultural Research, Hungarian Academy of Sciences, Budapest, P.O.B. 102, H-1525 Hungary; Klára H Otta, Department of Chemical Technology and Environmental Chemistry, L. Eötvös University, P.O.B. 32, Budapest 112, H-1518 Hungary

* author to whom correspondence should be addressed: katay.gyorgy@agrar.mta.hu 


\section{Abstract}

A method, including solid phase extraction sample preparation, overpressured layer chromatographic separation and subsequent densitometric evaluation, was developed for measurement of total resveratrol (cis- and trans-isomers) content of wine. The amount of resveratrol was determined in wine samples from different winemaking regions of Hungary. The total resveratrol was high in Hungarian red wines $(3.6-11 \mathrm{mg} / \mathrm{L})$, and much lower in white ones $(0.04-1.5 \mathrm{mg} / \mathrm{L})$. 


\section{Introduction}

The stilbene derivative, trans-resveratrol (TR, trans-3,5,4'-trihydroxystilbene, Figure 1) is a phytoalexin accumulated in a large number of plant species to protect them from microbial infections (e.g. toxin producing fungi) [1] and abiotic stresses (e.g. heavy metal ions, UV light exposure) $[2,3]$. TR is commonly present in grater portions in grapes and consequently in wines $[4,5]$. Cis-resveratrol (CR), the geometric isomer of TR, does not occur in blue grapes, but it is formed during the storage of the wine, so it is present in wines usually in much lower concentration than TR $[6,7]$. However, in some Brazilian wines the concentration of CR was five times higher than that of the trans isomer [8]. Earlier studies show that there is a significant difference in the TR content of white and red wines, due to the different winemaking technologies: red wines usually contain higher amount of TR than white ones $[9,10]$. It was reported that, in contrast to the wines, there is no considerable difference between the respective parts of white and blue grape varieties in TR content [11].

It has been established that TR has diverse beneficial activities which can be divided into two main groups [12]. The first group includes chemopreventive (e.g. antimutagenic, antioxidant and cardioprotective) effects $[13,14]$, and the second one means the killing/inhibiting effects (e.g. antibacterial, antifungal and anticancer activities) $[15,16]$.

The production of TR in grape berries was first reported by JEANDET et al. in 1991 [4]. Since this time, several methods have been developed for determining resveratrol (R, cis- and trans) and other poliphenols (e.g. quercetin, catechin, epicatechin) in grape berries, juices and wines. Electroanalytical methods for determination of polyphenols are relatively sparse in the literature. Voltammetric techniques are used for evaluation of total and individual poliphenols. Pekec et al. [17] described a sensitive electroanalytic method for determination of TR in grape samples by using a cyclodextrin modified carbon paste electrode applying 
differential pulse voltammetry. Airado-Rodriguez et al. [18] published a method for evaluation of TR with low detection limit using adsorptive stripping square-wave voltammetry at glassy carbon electrode.

The widely used methods are based on high-performance liquid chromatographic (HPLC) separation with UV [6, 19-22], photodiode array [23-26], fluorometric [27, 28], electrochemical $[11,29]$, or mass spectrometric $[10,30,31]$ detection. Gas chromatography coupled with mass spectrometry (GC-MS) [32, 33,] and capillary electrophoresis (CE) [3436] are less frequently used techniques for analysis of the polyphenolic components of wines and grapes.

In accordance with the scientific-technical progress, some of authors published recent years ultra performance liquid chromatographic (UPLC) methods for analysis of $\mathrm{R}$ and other polyphenolic compounds [37, 38].

Planar layer liquid chromatography provides the facility of the parallel analysis of samples, which can make faster the analysis, and requires less mobile phase than the HPLC, therefore, it is cheaper and more environment friendly. However, the thin-layer chromatography (TLC) is not widely used for analyses of $\mathrm{R}$ and other polyphenolic compounds of grapes and wines because of their limitations connected to the quality of separation and sensibility. Chen et al. [39] used TLC and fluorescence detection to determine the CR, and TR and piceid.

We developed measurement of $\mathrm{R}$ by overpressured layer chromatographic (OPLC) separation after liquid-liquid extraction sample preparation [40]. OPLC [41, 42] integrates the benefits of TLC and HPLC. It is a forced flow technique, using external pressure on TLC plate sealed on the edges and a pump system for the admission of mobile phase into the stationary phase. We compared TLC to an automatic OPLC technique for separation of stilbene isomers, implicating the $\mathrm{R}$ isomers, from wine [43]. The results clearly show that 
OPLC is more efficient than TLC, giving better resolution and higher theoretical plate number.

In connection with the sample preparation of wines, usually liquid-liquid extraction (LLE) $[44,45]$ or solid phase extraction (SPE) [46-48] are applied. SPE is very useful with its advantages such as high selectivity, reproducibility, facility of the preparation of more samples simultaneously, the automation of the process and it demands less solvent than LLE. Some authors published methods where samples are injected directly in the chromatograph without preparation $[17-19,49]$.

The aim of our study was to develop a relatively cheap and fast method for determination of total $\mathrm{R}$ in wines, using SPE sample preparation, OPLC separation and densitometric evaluation of chromatograms. We applied this method for analyses of some red and white wine samples from different wine regions of Hungary.

\section{Experimental}

\subsection{Materials}

TR was purchased from Sigma Aldrich Ltd. (Budapest, Hungary). Analytical grade solvents (Merck KGaA, Darmstadt, Germany) were used for solid phase extraction (SPE) and the water was deionized by Milli-Qplus, Ultra-Pure Water System from Millipore Co. (Billerica, MA, USA). Solvents used for OPLC were purchased from Reanal Ltd. (Budapest, Hungary). LiChrolut $^{\circledR}$ RP-18 columns (40-63 $\mu \mathrm{m}$; Merck KGaA, Darmstadt, Germany) with $500 \mathrm{mg}$ sorbent was applied for SPE. Drying of SPE cartridges and solvent evaporation after SPE were carried out in a nitrogen stream (99.95\%). Analytical OPLC was performed on $200 \mathrm{~mm}$ $\times 200 \mathrm{~mm}$ HPTLC silica gel $60 \mathrm{~F}_{254}$ adsorbent plates (Merck KGaA, Darmstadt, Germany) sealed on all four edges [41]. 


\subsection{Instrumentation}

For SPE, a Lichrolut ${ }^{\circledR}$ extraction unit (Merck KGaA, Darmstadt, Germany) was employed, coupled to a water-jet vacuum pump. A Rotavapor R-134 (Büchi Labortechnik AG, Flawil, Switzerland) apparatus was used for evaporation of solvents under reduced pressure. OPLC separation [41, 42] for quantitative determination of $\mathrm{R}$ was performed by using an automatic OPLC 50 BS instrument (OPLC-NIT Ltd., Budapest, Hungary). Solutions were applied to the chromatoplates with a Linomat IV-Y sample applicator (Camag Co., Muttenz, Switzerland). Chromatograms were evaluated instrumentally with a Shimadzu CS-930 dual-wavelength TLC scanner (Shimadzu Co., Kyoto, Japan) at $\lambda=310 \mathrm{~nm}$.

\subsection{Methods}

\subsubsection{Sample preparation}

RP-18 SPE columns were used for sample preparation. The column had previously been activated with $5 \mathrm{~mL}$ methanol followed by $5 \mathrm{~mL}$ water. After the preconditioning, $5 \mathrm{~mL}$ of wine was applied to the column. The column was washed with $10 \mathrm{~mL}$ water at $\mathrm{pH}=7.4$ (adjusted with a buffer of $\mathrm{K}_{2} \mathrm{HPO}_{4}$ and $\mathrm{KH}_{2} \mathrm{PO}_{4}$ ), and dried with a nitrogen gas stream for 30 min. Elution was performed with $10 \mathrm{~mL}$ ethyl acetate. The eluate was evaporated in vacuum at $35^{\circ} \mathrm{C}$, and redissolved in $0.5 \mathrm{~mL}$ methanol.

\subsubsection{Chromatographic separation}

Samples were applied $30 \mathrm{~mm}$ from the edge of the layer. The other OPLC conditions were as follows: the mobile phase was chloroform-methanol $(10: 1, \mathrm{v} / \mathrm{v})$, external pressure 50 bar, the rapid mobile phase flush $350 \mu \mathrm{L}$, development volume $8000 \mu \mathrm{L}$, the flow rate of the mobile 
phase $350 \mu \mathrm{Lmin}^{-1}$, and the development time was $1381 \mathrm{~s}$ [41]. In this system, CR and TR are not separated, they were measured together. The development distance was $157 \mathrm{~mm}$.

\section{Results and Discussion}

A method was developed for measurement of $\mathrm{R}$ including SPE sample preparation, OPLC separation and densitometric evaluation. This SPE and the earlier demonstrated LLE [43] sample preparations were compared. Besides of the mentioned advantages of SPE it also provides clearer extracts, which can be observed in densitograms (Figure 2). Because of the better resolution (there is no disturbing peak) the adsorbent layer is more loadable, so the limit of detection is lower in the case of SPE sample preparation $\left(0.03 \mathrm{mgL}^{-1}\right)$ than at LLE $(0.08$ $\left.\mathrm{mgL}^{-1}\right)$

The recovery was determined using a Cabernet Sauvignon red wine which contains $1.43 \mathrm{mgL}^{-}$

${ }^{1} \mathrm{R}$. The wine was spiked with a methanol solution of TR test substance so, that the $\mathrm{R}$ content was $3 \mathrm{mgL}^{-1}$ high. Comparing the chromatograms in Figure 2 (b and c), the difference can be seen in the peak of $\mathrm{R}$ indicates the increase of the amount of $\mathrm{R}$ because of the spiking. The recovery was $95 \%(\mathrm{SD}=2 \%, \mathrm{n}=3)$, which was calculated from the data included in Table 1. Data were obtained using the calibration curve (Figure 3), which linearity was proved in the range of $0.05-0.5 \mu \mathrm{g}$.

Wine samples were analyzed, originating from different traditional wine regions of Hungary and from various vintages. Similarly to earlier studies $[9,10]$, high amounts of $\mathrm{R}$ were measured in Hungarian red wines. The concentrations in R of red wines ranged from 3 to 13 $\mathrm{mgL}^{-1}$. While in white wine samples, $\mathrm{R}$ showed lower concentration, typically from 0.1 to $0.25 \mathrm{mgL}^{-1}$ (Table 2). It was established that the concentration of $\mathrm{R}$ in wine depends on the vintage, the varieties of grapes, the time of harvest, the making process $[44,50]$. These 
influences can cause the variances of the amount of $\mathrm{R}$ in the wine samples tested as well. However, the main reason for the difference between the amount of $\mathrm{R}$ in red and white wines can be originated from the winemaking technology, especially the fermentation on the skin, which is typical only for red wine.

TR is one of the active ingredients in red wines, which might contribute to the French paradox [51], that is the low incidence of coronary heart disease despite of high fat intake. It is known that the Hungarian cuisine is a bit fatty, and there are many people suffering in coronary heart disease in the country $[52,53]$. It is possible to get well this status, because in the last years the amount of the red wine consumer was increased in Hungary and the experiments show high amount of $\mathrm{R}$ in Hungarian red wines. It has to be pointed out that besides TR, there are other stilbenes [54] and other biologically active components (e.g. flavonoids or terpenoids) $[55,56]$ in red wines responsible for different beneficial effects.

It can be said that the exploitation of the special advantages of OPLC technique can be carried out with the use an efficient sample preparation (e.g. SPE) and a modern quantitative evaluation. However, a logical effort is the further exploitation of this efficient planar layer liquid chromatographic technique for the separation of $\mathrm{R}$ and other ingredients from grapes and wines. It means e.g. the use of the flowing eluent wall (FEW) operating mode [57], the two-dimensional technical solution [58] and especially the biological detection possibility which can be solved only in the field of layer liquid chromatography [59].

\section{Conclusion}

Our results clearly illustrate the applicability of OPLC to the analysis of $\mathrm{R}$ in white and red wines on the basis of SPE followed by a simple separation on HPTLC silica gel layer. There 
were significant differences between the $\mathrm{R}$ content of white and red wines, amounts varied between 0.04 (Chardonnay 2004, Eger) and $11.0 \mathrm{mgL}^{-1}$ (Pinot noir P.1. 2002).

\section{References}

[1] L. Bavaresco, S. Vezzulli, P. Battilani, P. Giorni, A. Pietri, T. Bertuzzi, J. Agric. Food Chem. 21 (2003) 6151-6157.

[2] J. Martinez, J.J. Moreno, Biochem. Pharmacol. 59 (2000) 865-870.

[3] R.A. Dixon, Nature 411 (2001) 843-847.

[4] P. Jeandet, R. Bessis, B. Gautheron, Amer. J. Enol. Vitic. 42 (1991) 41-46.

[5] E.H. Siemann, L.L. Creasy, Amer. J. Enol. Vitic. 43 (1992) 49-52.

[6] A.I. Romero-Perez, R.M. Lamuela-Raventos, C. Andres-Lacueva, M.C. de La TorreBoronat, J. Agric. Food Chem. 49 (2001) 210-215.

[7] H. Schmandke, Ernahr. Umsch. 49 (2002) 349-352.

[8] X. Vitrac, A. Bornet, R. Vanderlinde. J. Valls, T. Richard, J.C. Delaunay, J.M. Merillon, P.L. Teissedre, J. Agric. Food Chem. 14 (2005) 5664-5669.

[9] L.L. Creasy, M.T. Creasy, Pharm. Biol. 36 (1998) 8-13.

[10] G. Dugo, F. Salvo, P. Dugo, G.L. La Torre, L. Mondello, Drugs Exp. Clin. Res. 29 (2003) 189-202.

[11] I. Kolouchová-Hanzlíková, K. Melzoch, V. Filip, J. Smidrkal, Food Chem. 87 (2004) $151-158$.

[12] E. Tyihák, Gy. Kátay, Zs. Király-Véghely, Zs. Németh, L. Albert, B. Szende, Acta Hort. 597 (2003) 159-165.

[13] F. Uenobe, Si. Nakamura, M. MiyazawaMut. Res. 373 (1997) 197-200.

[14] E. Waddington, I.B. Puddey, K.D. Croft, Am. J. Clin. Nutr. 79 (2004) 54-61.

[15] J.L. Ingham, Phytochem. 15 (1976) 1791-1793. 
[16] G.B. Mahady, S.L. Pendland, Am. J. Gastroenterol. 95 (2000) 18-49.

[17] B. Pekec, A. Oberreiter, S. Hauser, K. Kalcher, A. Ortner, Int. J. Electrochem. Sci. 7 (2012) 4089-4098.

[18] D. Airado-Rodriguez, T. Galeano-Diaz, I. Duran-Meras, Food Chem. 122 (2010) 13201326.

[19] D.M. Goldberg, E. Ng, A. Karumanchiri, J. Yan, E.P. Diamandis, G J. Soleas, J. Chromatogr. A 708 (1995) 89-98.

[20] Z. Kerem, B.A. Bravdo, O. Shoseyov, Y. Tugendhaft, J. Chromatogr. A 1052 (2004) 211215.

[21] A.M. Tarola, F Milano, V Giannetti, Anal. Letters 40 (2007) 2433-2445.

[22] A.Zotou, E. Frangi, Chromatographia 67 (2008) 789-793.

[23] D.M. Goldberg, E. Tsang, A. Karumanchiri, E.P. Diamandis, G.J. Soleas, E. Ng, Anal. Chem. 68 (1996) 1688-1694.

[24] C. Dominguez, D.A. Guillen, C.G. Barroso, J Chromatogr A 918 (2001) 303-310.

[25] M. Esna-Ashari1, M. Gholami1, M.A. Zolfigol, M. Shiri, A. Mahmoodi-Pour, M. Hesari, Chromatographia 67 (2008) 1017-1020.

[26] L. Paulo, F. Domingues, J.A. Queiroz, E. Gallardo, J. Agric. Food Chem. 59 (2011) $2157-2168$.

[27] R. Pezet, V. Pont, P. Cuenat, J. Chromatogr. A 663 (1994) 191-197.

[28] A.R.B. de Quiros, J. Lopez-Hernandez, P. Ferraces-Casais, M.A. Lage-Yusty, J. Sep. Sci. 30 (2007) 1262-1266.

[29] K.D. McMurtrey, J. Minn, K. Pobanz, T.P. Schultz, J. Agric. Food Chem. 42 (1994) 2077-2080.

[30] J.B. Jean-Denis, R. Pezet, R. Tabacchi, J Chromat. A. 1112 (2006) 263-268. 
[31] L. Jaitz, K. Siegl, R. Eder, G. Rak, L. Abranko, G. Koellensperger, S. Hann, Food Chem. 122 (2010) 366-372.

[32] D.M. Goldberg, J. Yan, E. Ng, E.P. Diamandis, A. Karuman-chiri, G.J. Soleas, A.L. Waterhouse, Anal. Chem. 66 (1994) 3959-3963.

[33] G.J. Soleas, D.M. Goldberg, E.P. Diamandis, A. Karuman-chiri, J. Yan, E. Ng, Am. J. Enol. Vitic. 46 (1995) 346-352.

[34] L. Arce, M. T. Tena, A. Rios, M. Valcarcel, Anal. Chim. Acta, 359 (1998) 27-38.

[35] Y.Y. Peng, Q.C Chu, F.H. Liu, J.N. Ye, J. Agric. Food Chem. 52 (2004) 153-156.

[36] R.G. Peres, G.A. Micke, M.F.M. Tavares, D.B. Rodriguez-Amaya, J. Sep Sci. 32 (2009) $3822-3828$.

[37] L. Boutegrabet, A. Fekete, N. Hertkorn, Y. Papastamoulis, P. Waffo-Téguo J.M. Mérillon, P. Jeandet, R.D. Gougeon, P. Schmitt-Kopplin, Anal. Bioanal. Chem. 401 (2011) 1513-1521.

[38] T. Stark, N. Wollmann, S. Losch, T. Hofmann, Anal. Chem. 83 (2011) 3398-3405.

[39] M. Chen, Y.Q. Shu, J.G. He, Y.Q. Dai, Chinese J. Anal. Chem. 33 (2005) 635-638.

[40] Zs. Király-Véghely, E. Tyihák, L. Albert, Zs.I. Németh, Gy. Kátay, Acta Biol. Hung. 49 (1998) 281-289.

[41] E. Mincsovics, M. Garami, L. Kecskés, B. Tapa, Z. Végh, G. Kátay, E. Tyihák, J. AOAC Int. 82 (1999) 587-598.

[42] E. Mincsovics, M. Manach, L. Kecskés, B. Tapa, D. Papillard, E. Tyihák, J. Liq. Chrom. \& Rel. Technol. 26 (2003) 2611-2627.

[43] Zs. Király-Véghely, Gy. Kátay, E. Tyihák, J.M. Merillon, J. Planar Chromatogr. 17 (2004) 4-8.

[44] P. Jeandet, R. Bessis, M. Sbaghi, P. Meunier, P. Trollat, Am. J. Enol. Vitic. 46 (1995) 14. 
[45] I.N. Nicolaou, C.P. Kapnissi-Christodoulou, Electrophoresis 31 (2010) 3895-3902.

[46] J.A.B. Baptista, J.F.D. Tavares, R.C.B. Carvalho, Food Res. Int. 34 (2001) 345-355.

[47] L. Mercolini, M.A. Saracino, F. Bugamelli, A. Ferranti, M. Malaguti, S. Hrelia, M.A. Raggi, J. Sep. Sci. 31 (2008) 1007-1014.

[48] E. Porgali, E. Büyüktuncel, Food Res. Intern. 45 (2012) 145-154.

[49] A. Rodríguez-Bernaldo de Quirós, M.A. Lage-Yusty, J. López-Hernández, Food Res. Int. 42 (2009) 1018-1022.

[50] F. Mattivi, C. Zulian, G. Nicolini, L. Valenti, Ann. NY Acad. Sci. 957 (2002) 37-56.

[51] S. Renaud, M. de Lorgeril, Lancet, 339 (1992) 1523-1526.

[52] L. Mark, E. Nagy, A. Kondacs, L. Deli, Public Health. 3 (1998) 197-201.

[53] I. Rodler, G. Zajkás, Ann. Nutr. Metab. 46 (2002) 49-56.

[54] A.L. Waterhouse, Wine phenolics. Ann. NY Acad. Sci. 957 (2002) 21-36.

[55] F. Hakimuddin, G. Paliyath, K. Meckling, Breast Cancer Res. Treat. 85 (2004) 65-79.

[56] Z. Pineiro, M. Palma, C.G. Barroso, Anal. Chim. Acta 513 (2004) 209-214.

[57] E. Mincsovics, G. Kátay, P.G. Ott, Zs. Király-Véghely, Á.M. Móricz, E. Tyihák, Chromatographia 62 (2005) S51-S56.

[58] A.M. Siouffi, J. Chromatogr. A 556 (1991) 81-94.

[59] L. Botz, B. Kocsis, S. Nagy, in: P. Warsford, A. Townshed, C. Poole (eds.), Encyclopedia of Analytical Science, Elsevier Acad. Press, Oxford, 2005. 


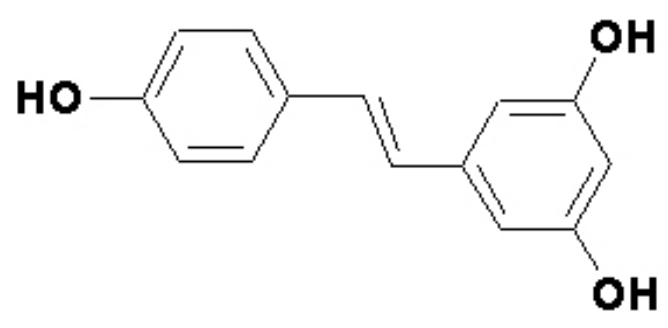

trans-resveratrol

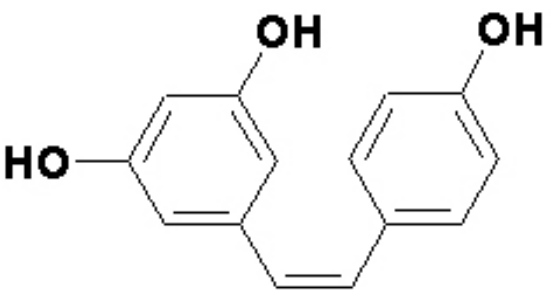

cis-resveratrol

Figure 1 

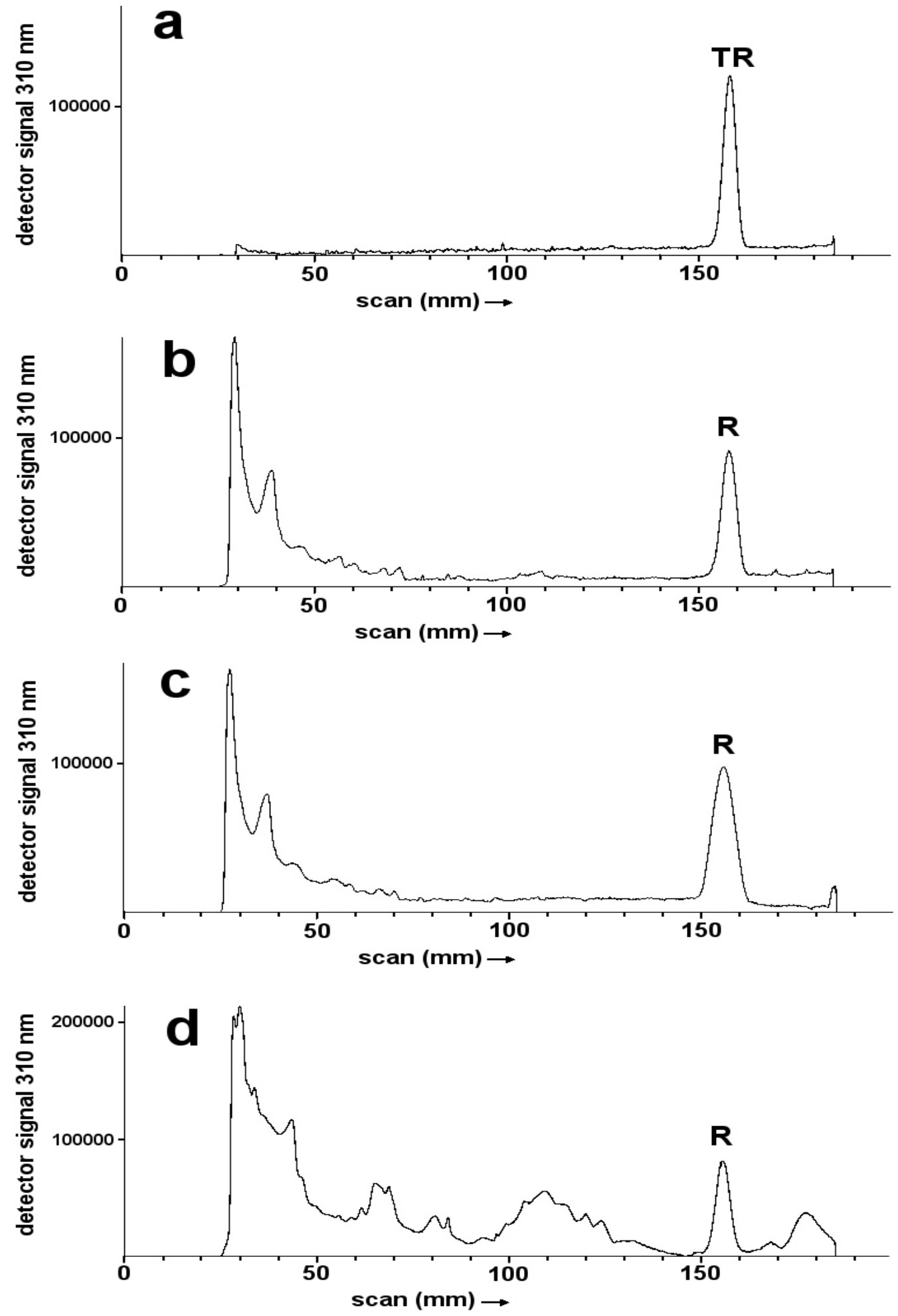

Figure 2 


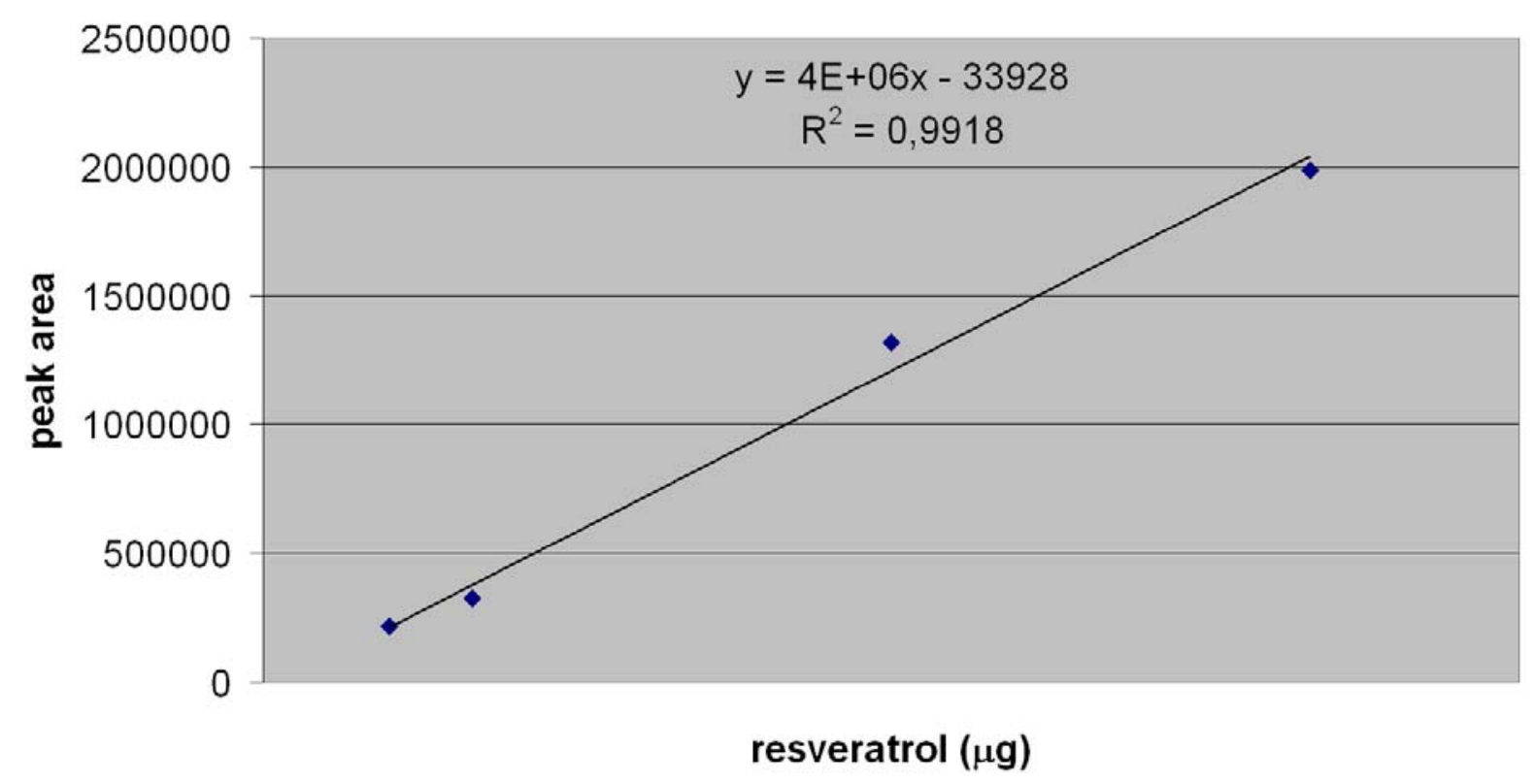

Figure 3 


\section{Captions to figures}

\section{Figure 1}

Chemical structure of trans- and cis-resveratrol.

\section{Figure 2}

Densitograms obtained from: trans-resveratrol test substance, a; SPE sample prepared Cabernet Sauvignon red wine, b; SPE sample prepared and spiked Cabernet Sauvignon red wine, c; LLE sample prepared Cabernet Sauvignon red wine, $\mathbf{d}$.

Figure 3 The calibration curve of resveratrol. 


\section{Table 1}

Data for the recovery of $\mathrm{R}$ from wine in three parallels. $3 \mathrm{mgL}^{-1} \mathrm{TR}$ was added to a Cabernet Sauvignon red wine.

\begin{tabular}{|l|c|c|c|c|c|}
\hline & \multicolumn{2}{|c|}{ R content of samples } & Average & Standard \\
& \multicolumn{2}{|c|}{$\left(\mathrm{mgL}^{-1}\right)$} & 3 & & (mgL $\left.{ }^{-1}\right)$ \\
& 1 & 2 & 3 & & \\
\hline I. Original cabernet Savignon & 1.36 & 1.49 & 1.44 & 1.43 & \pm 0.06 \\
II. Spiked Cabernet Savignon & 4.33 & 4.32 & 4.22 & 4.29 & \pm 0.06 \\
Differences (II.-1.43 $\left.\mathrm{mgL}^{-1}\right)$ & 2.97 & 2.89 & 2.79 & 2.86 & \pm 0.06 \\
Recovery & 97 & 96 & 93 & 95 & \pm 2.00 \\
\hline
\end{tabular}


Table 2

R content of some Hungarian red and white wines.

\begin{tabular}{|c|c|}
\hline Wine samples & Amount of resveratrol $\left(\mathrm{mgL}^{-1}\right)$ \\
\hline \multicolumn{2}{|c|}{ Red wines } \\
\hline Kékfrankos 2003, Villány & 3.6 \\
\hline Blauburger 2002 & 6.2 \\
\hline Gyöngyösdomoszló & \\
\hline Cabernet Sauvignon 2002 & 7.6 \\
\hline Gyöngyösdomoszló & \\
\hline Pinot noir P.1. 2002 & 11.0 \\
\hline Gyöngyösdomoszló & \\
\hline Kékfrankos 2003 & 8.5 \\
\hline Eger-Tóbérc & \\
\hline $\begin{array}{l}\text { Merlot } 2003 \text { Helvécia } \\
\text { Great Plain }\end{array}$ & 7.0 \\
\hline \multicolumn{2}{|c|}{ White wines } \\
\hline Leányka 2001, Eger & 1.5 \\
\hline Chardonnay 2004, Eger & 0.04 \\
\hline Tramini 2003 & 0.1 \\
\hline Gyöngyösdomoszló & \\
\hline Hárslevelü 2003 & 0.2 \\
\hline Tokaj & \\
\hline Sauvignon Blance & 0.09 \\
\hline Gyöngyösdomoszló & \\
\hline
\end{tabular}




\section{The Location of figures and tables in the text}

Location of Figure 1: first part of the chapter Introduction.

Location of Figure 2: at the beginning of the chapter Results and Discussion.

Location of Figure 3: the chapter Results and Discussion, after Figure 2.

Location of Table 1: the chapter Results and Discussion, after Figure 3.

Location of Table 2: the chapter Results and Discussion, after Table1. 